\title{
Sustainability and Functionality of Railway Network and its Connecting Facilities in Kosovo
}

\author{
Hazir S. Çadraku ${ }^{1 *} \odot$, Besa Jagxhiu \\ ${ }^{1}$ Faculty of Civil Engineering and Infrastructure, University for Business and Technology, Prishtina, Kosovo \\ Received 16 June 2020; Revised 14 August 2020; Accepted 21 August 2020; Published 01 September 2020
}

\begin{abstract}
The railway network presents a special communication function, which keeps humanity closer. The first developments of the railway network in Kosovo date back to 1874, when the first train entered this area from Thessaloniki through Skopje. This paper aims to provide some data generated during the year 2020 regarding the railway network in Kosovo and its connecting facilities. Construction of railway lines, stations, tunnels, bridges, watersheds, protective walls, and canals for surface water drainage has an average lifespan of 92 years. The total length of the railway network is $336.68 \mathrm{~km}$, in which are built 23 tunnels with a total length of $9789.5 \mathrm{~m} .26 .1 \%$ of them are of medium depth, while $73.9 \%$ are of shallow depth from the ground surface. $66.07 \%$ of the railway lines are active, while $33.42 \%$ are non-functional.
\end{abstract}

Keywords: Railway Network; Kosovo; Stations; Sustainable Railway Infrastructure; Tunnels.

\section{Introduction}

To recognize and understand the development and importance of the railway network in Kosovo, it is necessary to consider its historical circumstances. It has been over 147 years since the first construction of the railway, which connected the southern part with the northern part of Kosovo, and those creating connections with two important capitals, Skopje (North Macedonia) and Thessaloniki (Greece). The greatest development of the railway network and the associated facilities in Kosovo occurred from 1926 to 1960/1963. On this railway network, there are several facilities like stations, bridges, tunnels, canals, protective walls, watersheds, etc. Stations are places where vehicles stop and depart, making a round trip to transport passengers and goods. There are main and secondary stations in the railway network. Figure 1 shows the types of stations according to the architecture of their construction. They represent a very characteristic feature in the country's architectural and cultural identity $[1,2]$. Although most of them are severely damaged, the historical value of the station buildings cannot be ignored. They imprint the historical and cultural memory of a place, and people repay that prosperous era with new vitality [3, 4].

* Corresponding author: hazir.cadraku@ubt-uni.net

doi http://dx.doi.org/10. 28991/HEF-2020-01-03-02

$>$ This is an open access article under the CC-BY license (https://creativecommons.org/licenses/by/4.0/).

(C) Authors retain all copyrights. 

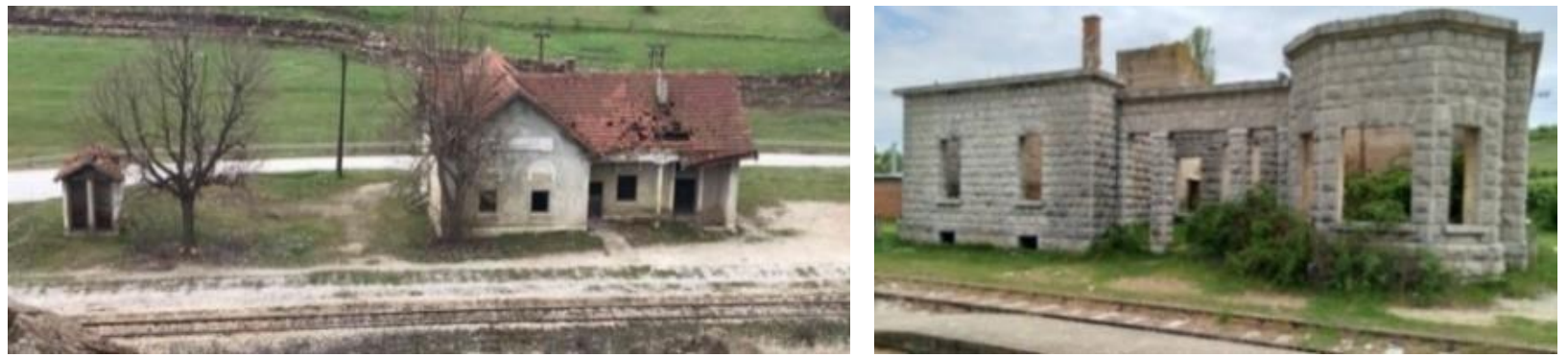

Figure 1. Types of stations in terms of architecture

Bridges are engineering facilities for crossing roads into rivers, valleys, or large slippery areas. Each bridge consists of supports and an aerial part, which is placed between the supports where it transmits the load of the bridge itself and the moving vehicles $[5,6]$. Its purpose is to connect two points at the shortest possible distance. Four types of bridges are identified on the railway lines (Figure 2). There are a total of 115 bridges with a length of 2.988m [7].
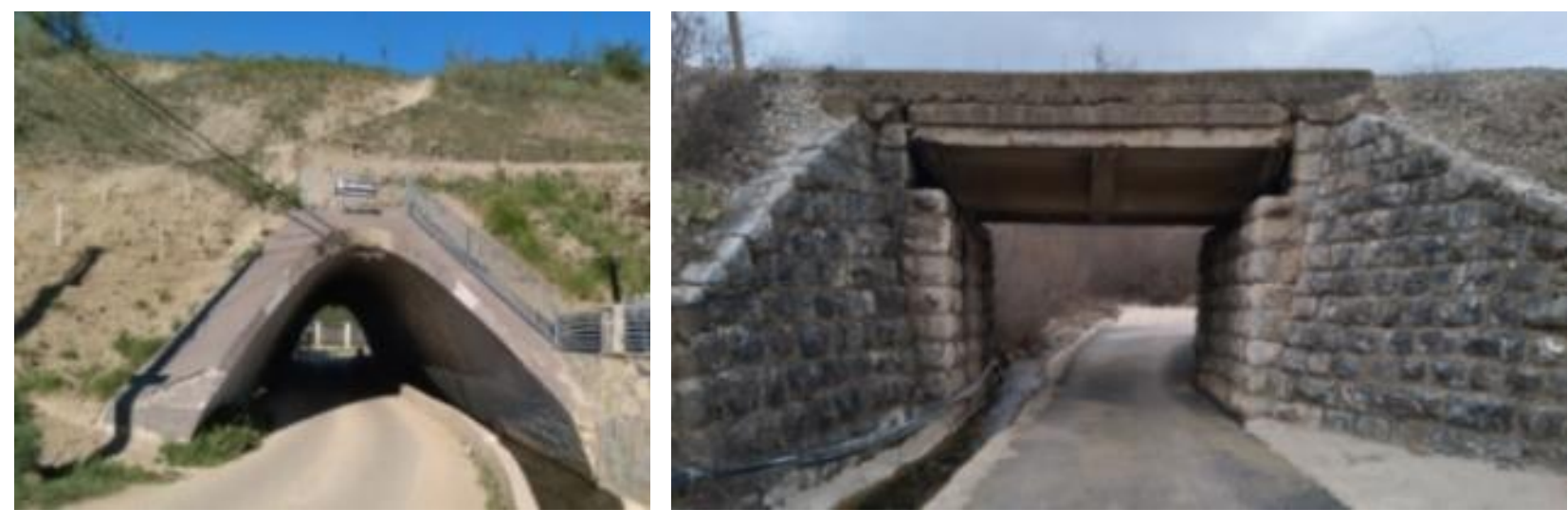

Figure 2. Types of bridges

Tunnels are underground engineering facilities that are located inside a rock massif [5]. A tunnel is a road that opens underground by piercing a mountain or a hill to pass by train or vehicle. Tunnels belong to the group of underground engineering facilities with a length much greater than their height and width. Tunnels, depending on the geological conditions of the region, may have different positions towards the geological structure. The tunnels under the railway tracks are built at an altitude of 331 to $654 \mathrm{~m}$, with an average height of $501 \mathrm{~m}$. The shape of tunnels that have been identified in Kosovo is a horseshoe shape (Figure 3), with a height of $6 \mathrm{~m}$ and a width of $2.60 \mathrm{~m}$.
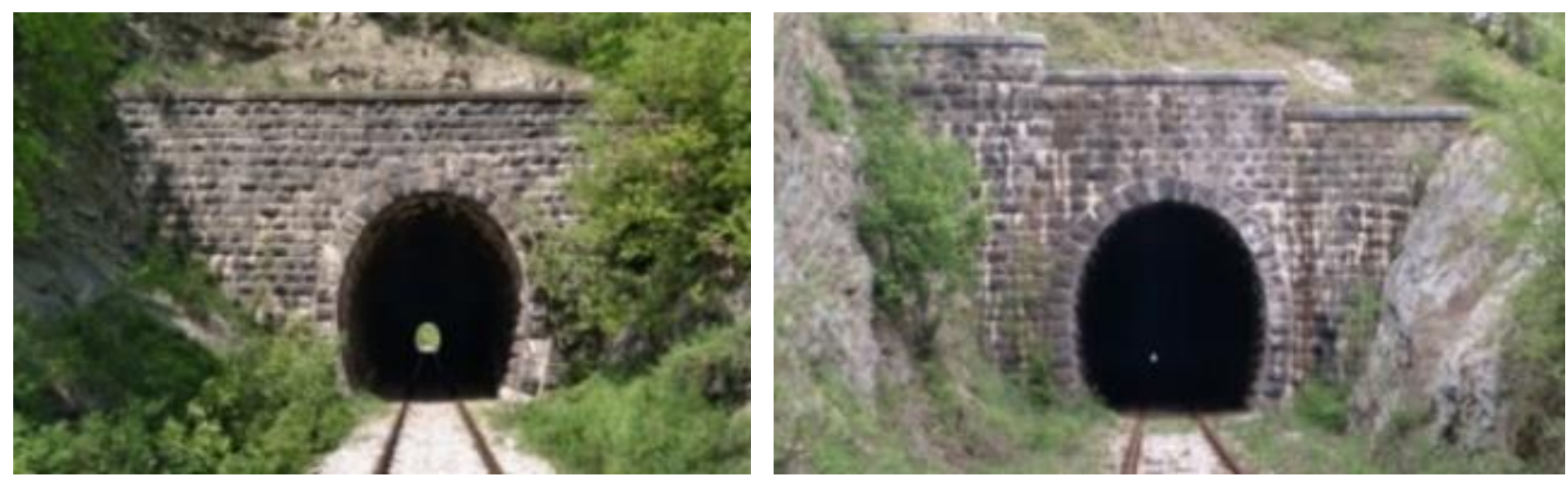

Figure 3. Tunnels shape

Watersheds are the places where water passes under the railway. The shape, dimensions, and building materials depend on the size of the catchment that carries water to the railway. During the research, we identified different types of watersheds in the railway network of Kosovo (Figure 4).

Protective walls are engineering structures built to prevent landslides. There are several of those engineering works on Kosovo's railways, which are built of rock material, but there are also concrete protective walls (Figure 5). 


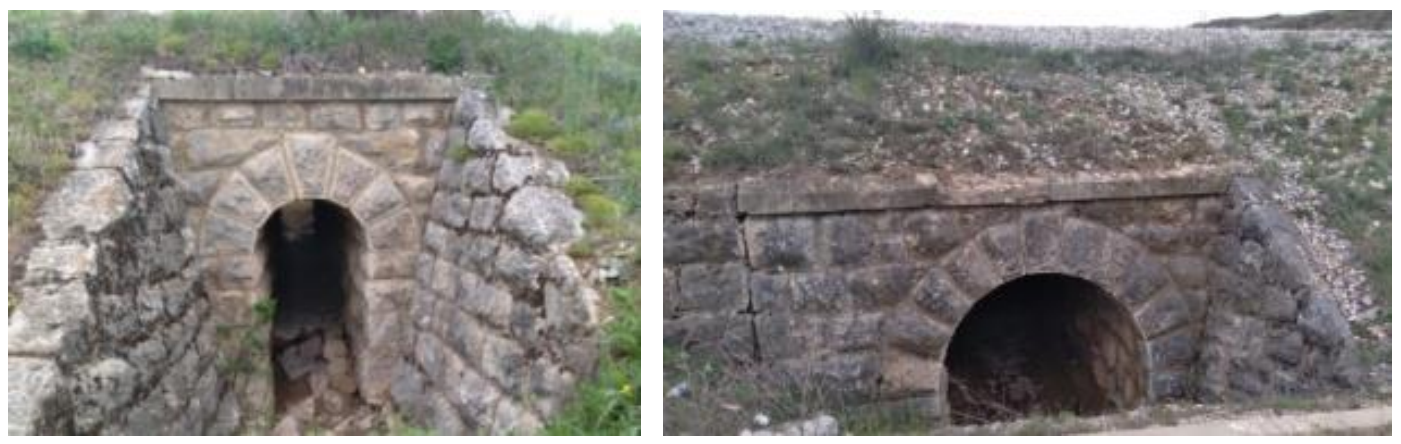

Figure.4. Watersheds shape

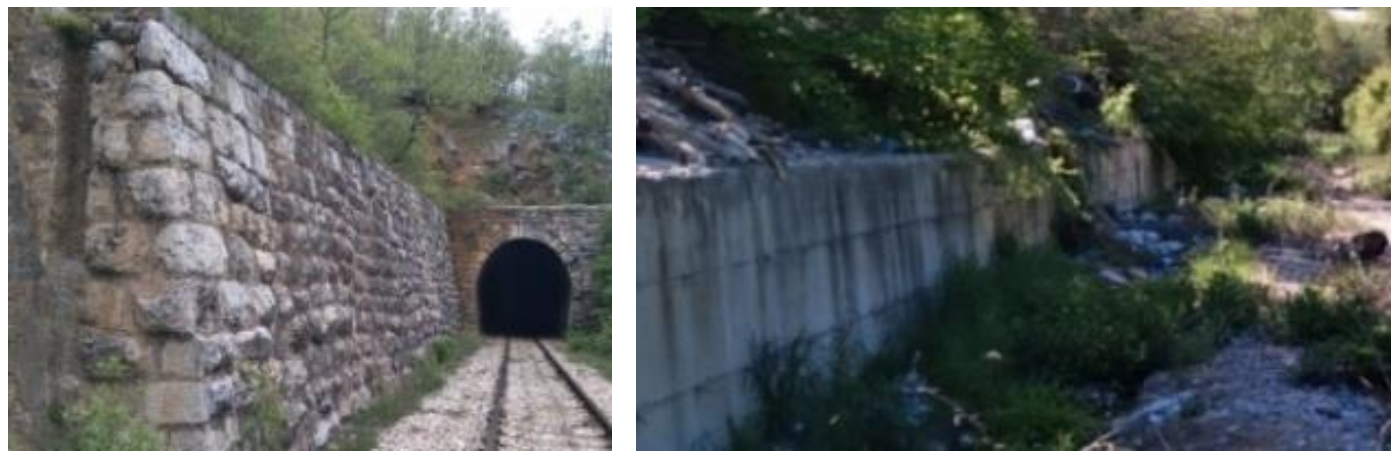

Figure 5. Types of protective walls

Canals are engineering facilities that aim to remove surface water that comes in the direction of the railway. They are made of concrete, with different shapes and dimensions (e.g. $\mathrm{L}_{1}=50 \mathrm{~cm} \mathrm{x} \mathrm{L}=40 \mathrm{~cm}, \mathrm{~h}=30 \mathrm{~cm} ; \mathrm{L}_{1}=50 \mathrm{~cm} \mathrm{x} \mathrm{L}=$ $30 \mathrm{~cm}, \mathrm{~h}=30 \mathrm{~cm}$ ) depending on the amount of water, respectively of the hydrological parameters of the area through, which pass the railway trail. This research identified only one form of canals, with different dimensions (Figure 6).
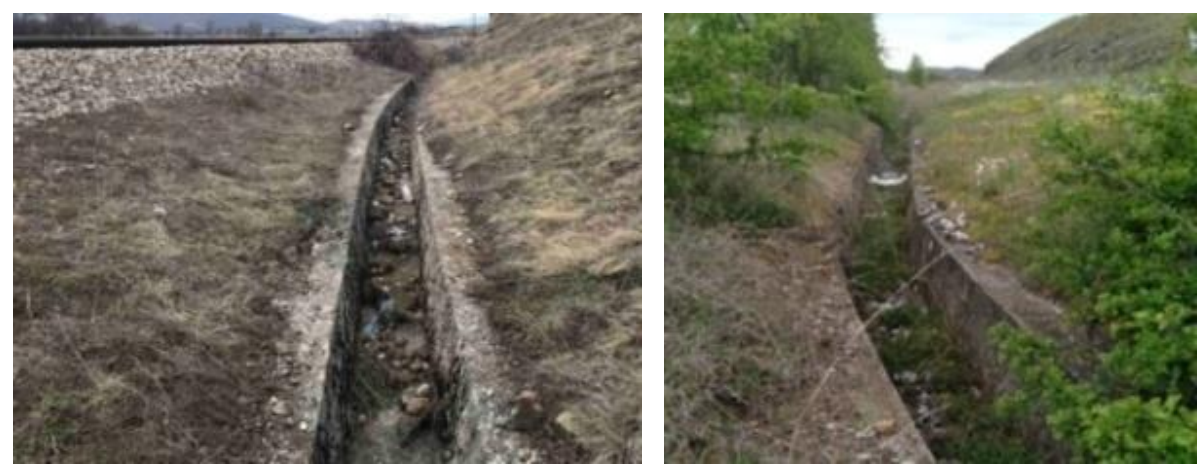

Figure 6. Types of channels

\section{Geological Construction}

The Çikatovo-Drenas tunnel is built on the Lower-Middle Triassic limestone "cT $\mathrm{T}_{1-2}$ " represented by meta-carbonate rocks-marbles, calcareous schists. The Baica-Terdevc-Drenas tunnel is built on the rock formations of the Drin-Ivanica element, Maastrichtian floor "sKmD" represented by sandstone, siltstone, marlstone (flysch). Gexhë tunnel in the formations of the Pashtrik Cretaceous, Coniacian-Maastrichtian floor is represented by limestone, marlstone, and calcarenite with chert "Kcn-mP". Tunnels Dresnik i Ulët-Klina and Pogragja-Toplan-Klina are built in formations Ks$\mathrm{mG}$, Pagarusha Cretaceous Maastrichtian floor, Santonian-Maastrichtian floor, thin-bedded limestone with chert (Ks$\mathrm{mG}$ ). Tunnels Ujëmirë-Klina and Ujëmirë I-Klina are built in the rock formations of the Drin-Ivanica element Maastrichtian floor represented by flysch (sandstone, siltstone, marlstone-flysch "sKmD" [8, 9].

The tunnel of Prishtina is built in the rock formations of the central area of Vardar Coniacian-Maastrichtian floor represented by limestone, marlstone, chert, calcarenite, partly conglomerate (calcareous flysch) "Ikcn-mC". Podujeva tunnel is built in the rock formations of the central area of Vardar Barremian-Aptian floor represented by sandstone, siltstone, conglomerate, partly marlstone (flysch) "Kb-ac" [10]. The Vllaq Tunnel is built in the rock formations Jurassic Magmatic Event Middle-Upper Jurassic floor represented by serpentinite. The Jellova tunnel is built on the rock formations of the Jurassic Magmatic Event Middle-Upper Jurassic floor represented by serpentinite "SJ $2-3$ ". Tunnels Ballaban and Kulla (Banjska) are built on the rock formations of the Jurassic Magmatic Event Middle-Upper Jurassic floor represented by peridotite, dunite, and partlyserpentinized " $\sigma \mathrm{J}_{2-3}$ ". 
The Pridvorci-Zveçan tunnel is built in rock formations of the Jurassic Magmatic Event Middle-Upper Jurassic floor represented by basalt " $\beta \mathbf{J}_{2-3}$ ". The Tvergjane-Leposavic tunnel is built in rock formations of the External Vardar Zone of the Coniacian-Maastrichtian floor represented by sandstone, siltstone, conglomerate, marlstone, limestone "SKcn$\mathrm{mE} "$. The Jerinje e Poshtme-Plavkovë tunnel is built in rock formations of the Cenozoic Magmatic Event OligocenePliocene floor represented by " $\alpha$ Eo-Nm" [11]. The Kaçanik i Vjetër-Stagovë tunnel is built in rock formations of the External Vardar Zone, the Coniacian-Maastrichtian floor represented by limestone, marlstone, siltstone (calcareous flysch) "fyKcn-mE". The Runjevo-Kaçanik tunnel is built in Lower Palaeozoic rock formations "cPz1" represented by marble, then in slabs represented by biotite gneiss, leptinitic gneiss "gPz1". Tunnel Gajre I is built in Paleozoic "mPz1" formations biotite muscovite schist. Tunnels Gajre II, III, IV, V are built in Paleozoic formations represented by biotite gneiss, leptinitic gneiss “gPz1" [9].

\subsection{Study Area}

The Republic of Kosovo is located in Southeastern part of Europe; it belongs to the countries of the Western Balkans. It extends in latitude from $41^{\circ} 50^{\prime} 58^{\prime \prime}$ to $43^{\circ} 15^{\prime} 42^{\prime \prime}$ and east longitude from $20^{\circ} 01^{\prime} 02^{\prime \prime}$ to $21^{\circ} 48^{\prime} 02^{\prime \prime}$ (Figure 7).

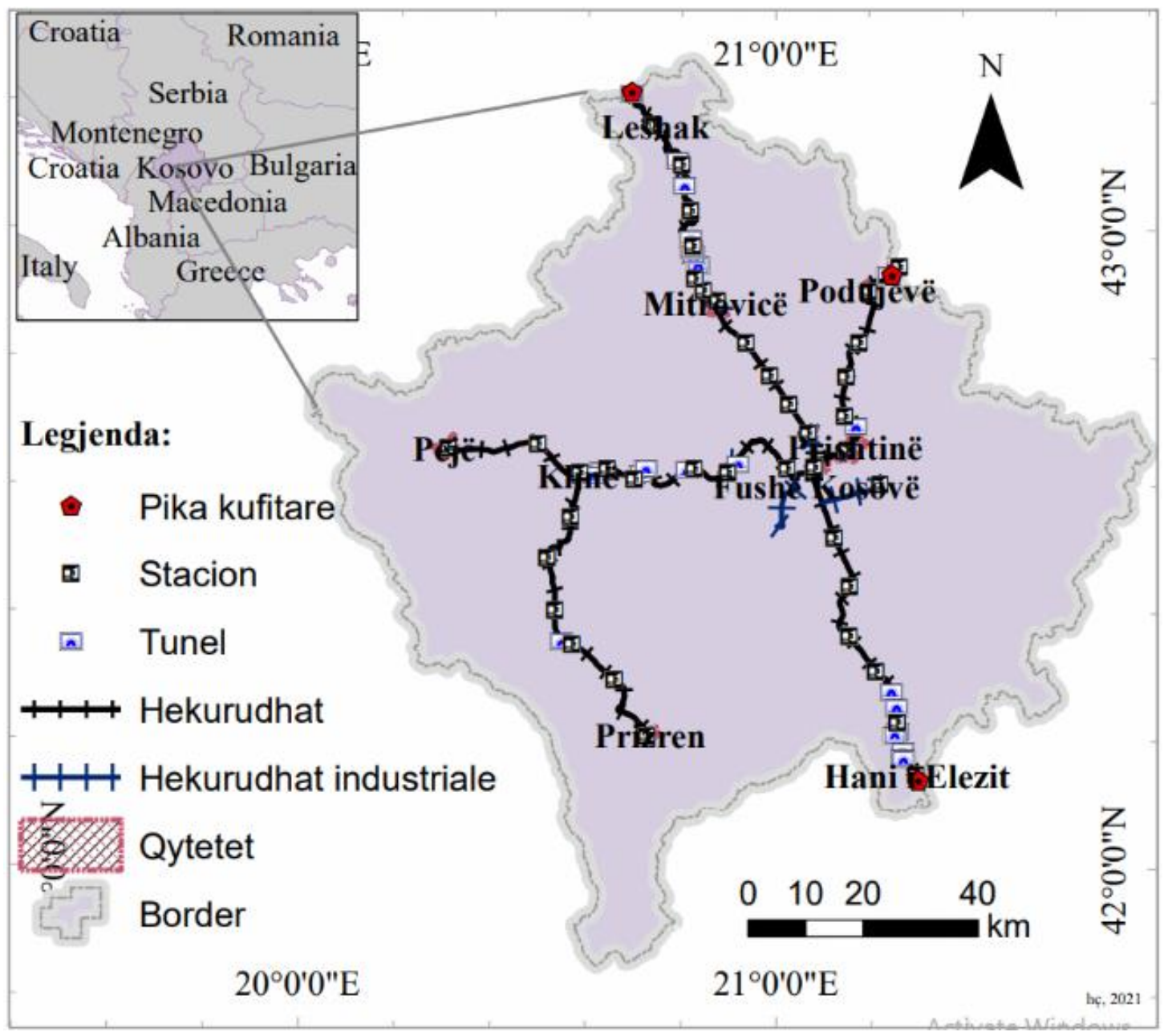

Figure 7. Map of study area

\section{Research Methodology}

The research methodology is based on two phases: the first phase of field research work and the second phase of office work (in figure 8 is shown in more extended form). Field research was carried out in different monthly stages during the year 2020. The following tools were used for field research: meter tape, GPS-Garmin, camera, notes from the field. The following working materials were used to achieve the goals of this paper: topographic maps of the territory of the Republic of Kosovo at a scale of 1:25000 [12], geological maps (1:100000 and 1:200000), satellite images from Google Earth, Arc Map v.10.1, Excel and field research visits. Topographic maps are georeferenced, and then the digitization of the railway network presented with line geometry is performed. Point and line geometry is used for the digitization of tunnels; polygon geometry is used for cities, while point and polygon geometry is used for stations, all in vector format. 


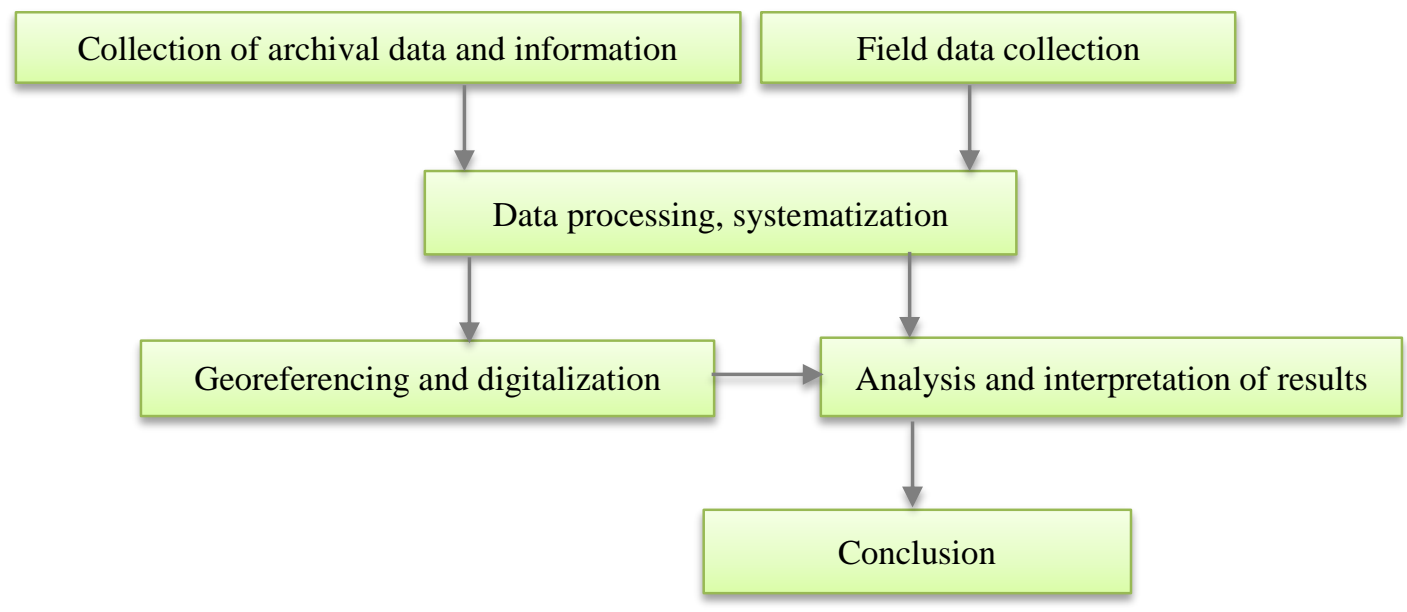

Figure 8. Flowchart of work methodology

\section{Results and Discussions}

The greatest development of the railway network and the associated engineering facilities in this area occurred from 1926 to 1960/1963. The data highlighted in this study (Table 1) shows that the total length of the network railway for general transport is $336.68 \mathrm{~km}$, of which, functional length is $237.34 \mathrm{~km}$, while $99.34 \mathrm{~km}$ is not functional. The longest railway line is Hani i Elezit-Fushë Kosovë-Mitrovica 98.25 km, then Klina-Prizren 58.74 km.

Table 1. Railway lines for general transport

\begin{tabular}{cccccc}
\hline No. & Railway line & Length $(\mathbf{k m})$ & Construction date & Lifespan (years) & Current status \\
\hline 1 & Hani i Elezit-Fushë Kosovë-Mitrovicë & 98.25 & xx.xx.1874 & 147 & Good (functional) \\
2 & Mitrovicë-Leshak & 41.94 & 12.02 .1931 & 90 & Good (functional) \\
3 & Leshak-Jarinje (Pllavkovë) & 9.32 & 12.02 .1931 & 90 & Good (functional) \\
4 & Fushë Kosovë-Prishtinë & 6.65 & 09.07 .1934 & 87 & Good (functional) \\
5 & Prishtinë-Podujevë (Merdar) & 40.60 & 07.07 .1948 & 73 & Not good (non-functional) \\
6 & Fushë Kosovë-Klinë-Pejë & 81.18 & 12.07 .1926 & 95 & Good (functional) \\
7 & Klinë-Prizren & 58.74 & xx.05.'"60-' 63 & 61 & Not good (non-functional) \\
\hline & Overall Length & $\mathbf{3 3 6 . 6 8}$ & Average & $\mathbf{9 1 . 8 6}$ & \\
\hline
\end{tabular}

Engineering facilities, according to their longevity and importance, are divided into five categories (Table 2) [5]:

Table 2. Lifespan of construction engineering facilities

\begin{tabular}{clcc}
\hline Category & \multicolumn{1}{c}{ Engineering Facility } & Lifespan (years) & Kosovo Railway Network \\
\hline Out of category & Monuments, Museums, Power Stations, etc. & Over 100 \\
& $\begin{array}{l}\text { Hydropower facilities, railways, central state capital buildings, } \\
\text { large industrial buildings }\end{array}$ & Over 60 \\
II & Factories and plants, communal facilities, simple buildings & Over $40 \quad$ Kosovo railways \\
III & Light facilities, massive residential constructions, etc. 40 & Less than 10 \\
IV & Temporary facilities & annels \\
\hline
\end{tabular}

Based on the categories, lifespan, and construction engineering facility (Table 2), it results that the railway network and its accompanying facilities enter into the first category. Referring to this categorization, it is noticed that all railway segments have survived the time in terms of their sustainability and functionality. Assessed from their lifespan, respectively years of construction, it results that the railway line Hani i Elezit-Fushë Kosovë-Mitrovicë has 147 years (Table 1) since the time it was built and is still functional, although, in recent years several projects have been developed for its repair (reconstruction) (funding from European Union).

Railway lines for industrial transport - the research showed that $49.56 \mathrm{~km}$ of railway networks are built for industrial transport purposes in Kosovo (Table 3). The longest line $(13.89 \mathrm{~km})$ of the industrial railway is the one that connects the Mining and Magnesite Industry "Golesh" with the railway station Bardh i Madh. This railway line is used today by the NewCo Enterprise "Ferronikeli" for the transport of nickel-iron from the mine "Gllavica" in Medveca-Lipjan, while the line from the mine "Gllavica" to the mine "Golesh" is not functional. 
Table 3. Industrial railway lines

\begin{tabular}{cccc}
\hline No. & Name of Railway Line & Length $(\mathbf{m})$ & Percentage (\%) \\
\hline 1 & Fabrika e këpucëve & 588.76 & 1.19 \\
2 & Fabrikapërpërpunimin e metaleve & 597.40 & 1.20 \\
3 & Remontiitrenave & 1943.80 & 3.92 \\
4 & Fabrika e sheqerit & 810.02 & 1.63 \\
5 & Miniera e Goleshitdheminiera e Hekur Nikelit & 13688.36 & 27.60 \\
6 & Fabrika e tekstilitKosova & 1382.49 & 2.79 \\
7 & TrafoZhitkovc & 435.91 & 0.88 \\
8 & FabrikaTrepça & 677.66 & 1.37 \\
9 & FabrikaTrepça (Metalurgjia) & 4518.86 & 9.11 \\
10 & Fabrika e PaimeveVodicë & 3537.81 & 7.13 \\
11 & TermocentraliKosova "A" & 3499.99 & 7.06 \\
12 & MinieraKizhnicë & 12481.31 & 25.16 \\
13 & MinieraKizhnicë & 522.22 & 1.05 \\
14 & Fabrika e vajit (M.Z) & 424.22 & 0.86 \\
15 & St. Drenas-Shkritorja e Feronikelit & 4491.18 & 9.05 \\
\hline \multicolumn{4}{r}{} \\
\hline
\end{tabular}

The research reveals that in the entire railway network of Kosovo, there are 23 tunnels with a total length of 9789.5 m (Table 4).

Table 4. Characteristic data of tunnels

\begin{tabular}{|c|c|c|c|c|c|c|}
\hline \multirow{2}{*}{ No. } & \multirow{2}{*}{ Name of the tunnel/Location/ } & \multirow{2}{*}{ Direction } & \multicolumn{2}{|c|}{ Coordinates } & \multirow{2}{*}{$\begin{array}{c}\mathbf{L}_{\mathrm{md}} \\
\mathrm{Z}(\mathbf{m}) \\
\end{array}$} & \multirow{2}{*}{$\begin{array}{c}\text { Length } \\
\text { (m) }\end{array}$} \\
\hline & & & $\mathbf{N}$ & $\mathbf{E}$ & & \\
\hline \multirow{2}{*}{1} & \multirow{2}{*}{ Ujë Mirë-Klinë } & Entrance (direction from Fushë Kosovë & $42^{\circ} 37^{\prime} 25^{\prime \prime}$ & $20^{\circ} 42^{\prime} 47^{\prime \prime}$ & 490 & \multirow{2}{*}{200} \\
\hline & & Exit (direction Peja) & 423720 & 204247 & 487 & \\
\hline \multirow{2}{*}{2} & \multirow{2}{*}{ Ujë Mirë I-Klinë } & Entrance (direction from Fushë Kosovë & 423746 & 204339 & 508 & \multirow{2}{*}{134} \\
\hline & & Exit (direction Peja) & 423748 & 204324 & 504 & \\
\hline \multirow{2}{*}{3} & \multirow{2}{*}{ Baicë-Terdevc-Drenas } & Entrance (direction from Fushë Kosovë & 423747 & 204856 & 654 & \multirow{2}{*}{1065} \\
\hline & & Exit (direction Peja) & 423730 & 204816 & 649 & \\
\hline \multirow{2}{*}{4} & \multirow{2}{*}{ Çikatovë-Drenas } & Entrance (direction from Fushë Kosovë & 423821 & 205512 & 586 & \multirow{2}{*}{316} \\
\hline & & Exit (direction Peja) & 423812 & 205506 & 585 & \\
\hline \multirow{2}{*}{5} & \multirow{2}{*}{ Prishtinë } & Entrance (direction from Fushë Kosovë & 424131 & 211025 & 642 & \multirow{2}{*}{1593} \\
\hline & & Exit (direction Podujevë) & 424209 & 210936 & 626 & \\
\hline \multirow{2}{*}{6} & \multirow{2}{*}{ Merdar-Podujevë } & Entrance (direction from Fushë Kosovë & 425551 & 211350 & 624 & \multirow{2}{*}{1690} \\
\hline & & Exit (direction Serbia) & 425609 & 211459 & 621 & \\
\hline \multirow{2}{*}{7} & \multirow{2}{*}{ Pogragjë-Toplan-Klinë } & Entrance (direction from Fushë Kosovë & 423738 & 203803 & 510 & \multirow{2}{*}{412} \\
\hline & & Exit (direction Peja) & 423733 & 203734 & 438 & \\
\hline \multirow{2}{*}{8} & \multirow{2}{*}{ Dresnik i Ulët-Klinë } & Entrance (direction from Fushë Kosovë & 423710 & 203650 & 435 & \multirow{2}{*}{402} \\
\hline & & Exit (direction Peja) & 423713 & 203634 & 434 & \\
\hline \multirow{2}{*}{9} & \multirow{2}{*}{ Gexhë-Rahovec } & Entrance (direction from Fushë Kosovë & 422138 & 203238 & 336 & 715 \\
\hline & & Exit (direction Prizren) & 422126 & 203303 & 331 & 715 \\
\hline 10 & 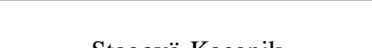 & Entrance (direction from Fushë Kosovë & 421650 & 211435 & 529 & 170 \\
\hline 10 & Stagove-Kaçanık & Exit (direction North Macedonia) & 421647 & 211433 & 525 & $1 / 8$ \\
\hline 11 & Dunioü Kononit & Entrance (direction from Fushë Kosovë & 421523 & 211512 & 526 & 205 \\
\hline 11 & Runjeve-Kaçanık & Exit (direction North Macedonia) & 421520 & 211514 & 515 & 205 \\
\hline 12 & Kacanik J (Gaire D) & Entrance (direction from Fushë Kosovë & 421114 & 211558 & 448 & 8827 \\
\hline 12 & Kaçanık I (Gajre 1) & Exit (direction North Macedonia) & 421112 & 211557 & 444 & 88.21 \\
\hline 13 & Kacanik II (Gaire II) & Entrance (direction from Fushë Kosovë & 421304 & 211524 & 484 & 100 \\
\hline 13 & Kaçanık II (Gajre II) & Exit (direction North Macedonia) & 421302 & 211522 & 484 & 100 \\
\hline
\end{tabular}




\begin{tabular}{|c|c|c|c|c|c|c|}
\hline \multirow{2}{*}{14} & \multirow{2}{*}{ Kaçanik III (Gajre III) } & Entrance (direction from Fushë Kosovë & $42^{\circ} 12^{\prime} 50^{\prime \prime}$ & $21^{\circ} 15^{\prime} 01^{\prime \prime}$ & 490 & \multirow{2}{*}{215} \\
\hline & & Exit (direction North Macedonia) & 421244 & 211458 & 484 & \\
\hline \multirow{2}{*}{15} & \multirow{2}{*}{ Kaçanik IV (Gajre IV) } & Entrance (direction from Fushë Kosovë & 421041 & 211552 & 430 & \multirow{2}{*}{338} \\
\hline & & Exit (direction North Macedonia) & 421034 & 211558 & 426 & \\
\hline \multirow{2}{*}{16} & \multirow{2}{*}{ Kaçanik V (Gajre V) } & Entrance (direction from Fushë Kosovë & 421030 & 211603 & 413 & \multirow{2}{*}{114} \\
\hline & & Exit (direction North Macedonia) & 421028 & 211608 & 415 & \\
\hline \multirow{2}{*}{17} & \multirow{2}{*}{ Vllaq-Zveçan } & Entrance (direction from Mitrovica) & 425655 & 205004 & 510 & \multirow{2}{*}{227} \\
\hline & & Exit (direction Serbia) & 425702 & 205003 & 512 & \\
\hline \multirow{2}{*}{18} & \multirow{2}{*}{ Jallovë-Zveçan } & Entrance (direction from Mitrovica) & 425748 & 204931 & 510 & \multirow{2}{*}{327} \\
\hline & & Exit (direction Serbia) & 425754 & 204920 & 516 & \\
\hline \multirow{2}{*}{19} & \multirow{2}{*}{ Ballaban-Zveçan } & Entrance (direction from Mitrovica) & 425816 & 204908 & 502 & \multirow{2}{*}{200} \\
\hline & & Exit (direction Serbia) & 425822 & 204909 & 508 & \\
\hline \multirow{2}{*}{20} & \multirow{2}{*}{ Kulle (Banjska) Zveçan } & Entrance (direction from Mitrovica) & 425914 & 204902 & 517 & \multirow{2}{*}{579} \\
\hline & & Exit (direction Serbia) & 425931 & 204900 & 511 & \\
\hline \multirow{2}{*}{21} & \multirow{2}{*}{ Pridvorci-Zveçan } & Entrance (direction from Mitrovica) & 430424 & 204817 & 479 & \multirow{2}{*}{76} \\
\hline & & Exit (direction Serbia) & 430424 & 204820 & 476 & \\
\hline \multirow{2}{*}{22} & \multirow{2}{*}{ Tvergjanë-Leposaviq } & Entrance (direction from Mitrovica) & 430641 & 204724 & 475 & \multirow{2}{*}{287} \\
\hline & & Exit (direction Serbia) & 430650 & 204723 & 464 & \\
\hline \multirow{2}{*}{23} & \multirow{2}{*}{ Jerinje e Poshtme-Pllavkovë } & Entrance (direction from Mitrovica) & 431256 & 204128 & 432 & \multirow{2}{*}{350} \\
\hline & & Exit (direction Serbia) & $43^{\circ} 13^{\prime} 08^{\prime \prime}$ & $20^{\circ} 41^{\prime} 30^{\prime \prime}$ & 435 & \\
\hline
\end{tabular}

The largest number of tunnels is in the railway line Fushë Kosovë-Hani i Elezit, a total of 7 tunnels with a length of $1216.5 \mathrm{~m}$, and Mitrovicë-Jarinje, a total of 7 tunnels with a length of $2046 \mathrm{~m}$. The third line in a row is Fushë KosovëKlina in which are 6 tunnels with a total length of $2529 \mathrm{~m}$ (Table 5). From table 5 it can be seen that although in the line Prishtina-Podujeva there are only 2 tunnels, this line dominates in terms of the length, with a total length of 3283 $\mathrm{m}$ or with $33.53 \%$ of the length of all tunnels in the railway network of Kosovo. The highest percentage in terms of the number of tunnels is the lines Fushë Kosovë-Hani i Elezit and Mitrovicë-Jarinje (Plavkovë) with 20.90\% (Table 5). The tunnels on the railway track are built at an altitude of $331 \mathrm{~m}$ (exit of the Gexhë tunnel) to $654 \mathrm{~m}$ (entrance to the Baica-Terdevc tunnel) with an average height of $501 \mathrm{~m}$. The shortest tunnel $76 \mathrm{~m}$ is in the locality Pridvorce, while the longest 1,690 $\mathrm{m}$ is in the locality Merdar, while the average length of the tunnels is $426 \mathrm{~m}$ (Table 1). The shape of the portals is mainly in the shape of a horseshoe, with a height of $6 \mathrm{~m}$ and a width of $260 \mathrm{~m}$ at the end, $290 \mathrm{~m}$ in the middle. The material, which is used for the tunnel portal cladding (entrance and exit) is rock. The dimensions of the rock blocks which are used for masonry range from 35,40 to $85 \mathrm{~cm}$. They were carved in certain parts before being placed.

Table 5. Number of tunnels in the Kosovo railway network

\begin{tabular}{cccccc}
\hline No. & Railway line & Number of tunnels & Percentage $(\boldsymbol{\%})$ & Length $(\mathbf{m})$ & Percentage $(\boldsymbol{\%})$ \\
\hline 1 & Fushë Kosovë-Hani iElezit (Bllacë) & 7 & 30.43 & 1216.7 & 12.43 \\
2 & Mitrovicë-Jarinje (Pllavkovë) & 7 & 30.43 & 2046 & 20.90 \\
3 & Fushë Kosovë-Klinë & 6 & 26.09 & 2529 & 25.83 \\
4 & Prishtinë-Podujevë (Merdar) & 2 & 8.70 & 3283 & 33.54 \\
5 & Klinë-Prizren & 1 & 4.35 & 715 & 7.30 \\
\hline \multicolumn{7}{r}{} & Total & 23 & 100.00 & 9789.7 & 100.00 \\
\hline
\end{tabular}

According to the standard GN206 [13] (Table 6), it results that the tunnels in the railway network of Kosovo are divided into two groups. In the first group belongs the tunnels with short length and in the second one those with medium length. $90.5 \%$ of tunnels in the railway network of Kosovo are of medium length.

Table 6. Division of tunnels by length

\begin{tabular}{cccc}
\hline Rank according to GN206 & Length & $\begin{array}{c}\text { Number of tunnels by length in the Kosovo } \\
\text { railway network }\end{array}$ & Percentage (\%) \\
\hline Very short & up to $50 \mathrm{~m}$ & 0 & 0 \\
Short & $50-100 \mathrm{~m}$ & 2 & 9.52 \\
Medium & $500-2200 \mathrm{~m}$ & 19 & 90.5 \\
Long & $2200-4000 \mathrm{~m}$ & 0 & 0 \\
Very long & above $4000 \mathrm{~m}$ & 0 & 0 \\
\hline
\end{tabular}


Referring to the division of tunnels according to depth from the ground surface [5], the research shows that 6 tunneles ose $26.1 \%$ of them have average depth and 17 tunnels or $73.9 \%$ of them have shallow below (Table 7).

Table 7. Division of tunnels by depth

\begin{tabular}{cccc}
\hline No. & Rank & $\begin{array}{c}\text { Depth of railway tunnels in Kosovo from the ground } \\
\text { surface (from the highest quota) }\end{array}$ & Percentage (\%) \\
\hline 1 & Very deep over 300 m & 0 & 0 \\
2 & Depth 100-300 m & 0 & 0 \\
3 & Average 50-100 m & 6 & 26.1 \\
4 & Shallow below 50 m & 17 & 73.9 \\
\hline & Total & $\mathbf{2 3}$ & $\mathbf{1 0 0}$ \\
\hline
\end{tabular}

Other engineering facilities like bridges, watersheds, protective walls, and water drainage canals are also constructed of environmental material combined with sand and river gravel for the preparation of mortar as the connecting elements of masonry. Seven shapes of tunnel opening are known (Table 8) [14, 15]. The selection of the shape of the tunnel, its position, lifespan, etc., depends on the geological conditions of the region, the position of the geological structure, and the purpose of its use (transport [16], hydrotechnical [17], municipal [18], mining [19]). This research shows that the shape of the tunnel on the Kosovo railways is horseshoe shaped and partly segmental.

Table 8. Geometric shapes of tunnels

\begin{tabular}{|c|c|c|c|c|}
\hline No. & Shape & Description & $\begin{array}{l}\text { Tunnel shape on } \\
\text { Kosovo Railways }\end{array}$ & Scheme \\
\hline 1 & Polycentric & $\begin{array}{l}\text { This tunnel shape has a number of centers and } \\
\text { provides a sufficient flat base for traffic movement. }\end{array}$ & There is no & \\
\hline 2 & Circular & $\begin{array}{l}\text { Circular tunnels are used to carry water under } \\
\text { pressure. These are not appropriate for traffic tunnels } \\
\text { because more filling is needed to make the base flat. }\end{array}$ & There is no & \\
\hline 3 & Rectangular & $\begin{array}{l}\text { For pedestrian traffic, rectangular shapes of tunnels } \\
\text { are appropriate. These types of tunnels are not suitable } \\
\text { to resist external pressure due to their rectangular } \\
\text { shape and these are not in use these days. }\end{array}$ & There is no & \\
\hline 4 & Egg-shaped & $\begin{array}{l}\text { This tunnel shape has a number of centers and radius } \\
\text { length. These are suitable as sewer tunnels to carry } \\
\text { sewage water. }\end{array}$ & There is no & \\
\hline 5 & Horseshoe & $\begin{array}{l}\text { Horseshoe tunnel shape is a combined shape of arches } \\
\text { and circular tunnel. These types of tunnels shape are } \\
\text { quite popular. }\end{array}$ & $\begin{array}{l}\text { Form of the tunnel } \\
\text { in Kosovo }\end{array}$ & \\
\hline 6 & Elliptical & $\begin{array}{l}\text { For carrying water, elliptical-shaped tunnels are } \\
\text { appropriate. These are suitable in softer material. For } \\
\text { better resistance to external pressure, the major axis of } \\
\text { this tunnel is maintained vertically. }\end{array}$ & There is no & \\
\hline 7 & Segmental & $\begin{array}{l}\text { Segmental tunnels are suitable for traffic tunnels. It is } \\
\text { a section with an arched roof and straight sides. These } \\
\text { are generally used for subways or navigation tunnels. }\end{array}$ & $\begin{array}{l}\text { Form of the tunnel } \\
\text { in Kosovo }\end{array}$ & \\
\hline
\end{tabular}




\section{Conclusion}

The railway network presents a special communication function. In Kosovo, it has a history of over 147 years. On this railway network, there are several engineering facilities like stations, bridges, tunnels, watersheds, canals, etc. Their size and construction depend on the circumstances of the time of their construction, as well as the material used for their construction. The geological construction through which the tunnels are built is diverse and includes geological formations of different ages and floors. The total length of the railway network for general transport is $336.68 \mathrm{~km}$, of which functional lengths are $237.34 \mathrm{~km}$, while $99.34 \mathrm{~km}$ are not functional. The railway network for industrial transport has a length of $49.56 \mathrm{~km}$. The lifespan of the railway network and the engineering facilities on it is over 90 years. The research revealed that in the entire railway network of Kosovo, there are 23 tunnels with a total length of $9789.5 \mathrm{~m}$. 90.5\% of the tunnels are medium-length tunnels. According to the results from the depth of the ground, $73.9 \%$ of them have an average depth. The tunnels on the railways in Kosovo have a horseshoe shape. Ancillary facilities like stations, bridges, canals, protective walls, watersheds, etc., are of different shapes and dimensions. From 1963 until nowadays, no new construction has been made in this network, except some projects for the repair (funding of the European Union) of a segment in the railway line Hani i Elezit-Fushë Kosovë-Mitrovica. Based on the research, it is concluded that in this railway network, intervention is required through a deeper analysis supported by technical analysis, laboratory analysis, etc., to bring to the standard state of operation the entire network and the engineering facilities attached to it.

\section{Declarations}

\subsection{Author Contributions}

Conceptualization, H.Ç. and B.J.; writing—original draft preparation, H.Ç. and B.J.; writing—review and editing, H.Ç. and B.J. All authors have read and agreed to the published version of the manuscript.

\subsection{Data Availability Statement}

The data presented in this study are available in article.

\subsection{Funding}

The authors received no financial support for the research, authorship, and/or publication of this article.

\subsection{Acknowledgements}

Thanks also to my family (parents, wife, brothers and sister) for financial support to achieve this goal.

\subsection{Institutional Review Board Statement}

Not applicable.

\subsection{Informed Consent Statement}

Not applicable.

\subsection{Declaration of Competing Interest}

The authors declares that there is no conflict of interests regarding the publication of this manuscript. In addition, the ethical issues, including plagiarism, informed consent, misconduct, data fabrication and/or falsification, double publication and/or submission, and redundancies have been completely observed by the authors.

\section{References}

[1] Jagxhiu, B., \& Çadraku, H. (2020). Identification and restoration of the traditional watermills in Lipjan. Pollack Periodica, 16(1), 145-150. doi:10.1556/606.2020.00206.

[2] Zhou, S. (2019). A Vehicle-Track-Tunnel-Soil Model for Evaluating the Dynamic Response of a Double-Line Underground Railway Tunnel in a Poroelastic Full-Space. Dynamics of Rail Transit Tunnel Systems, 41-68. doi:10.1016/b978-0-12-8183823.00003-7.

[3] Wu, M., He, H., \& Bachmann, B. (2020). The activation of industrial heritage: Transformation in the Petite Ceinture. Pollack Periodica. doi:10.1556/606.2021.00316.

[4] Dauwe, L., Fröhlich, B., \& Weidinger, A. (2018). Risk management during construction of a new road tunnel crossing under a 150 year old railway tunnel. Ce/papers, 2(2-3), 945-950. doi:10.1002/cepa.793.

[5] N. Konomi, (2002) "Engineering Geology - Geology of engineering works" (in Albanian), Libri Universitar, Tiranë, Albania.

[6] Liu, C., Peng, L., Lei, M., Shi, C., \& Liu, N. (2019). Fatigue Performance of Tunnel Invert in Newly Designed Heavy Haul Railway Tunnel. Applied Sciences, 9(24), 5514. doi:10.3390/app9245514. 
[7] Ministry of Environment and Spatial Planning (2020), Institute for Spatial Planning, Kosovo Spatial Plan 2010-2020+, Prishtinë, 2010. Available online: https://www.gov.si/en/state-authorities/ministries/ministry-of-the-environment-and-spatialplanning/ (accessed on April 2020).

[8] Lončarević, C. (1980). Basic Geological Map SFRJ, Orahovac K 34-42 (1:100000), 1959-1971. Geološki Institut, Belgrade, Serbia. 1980. (In Serbian).

[9] The Independent Commission for Mines and Minerals (2020), Geological Map (1:200000). Available online: https://www.kosovo-mining.org/ (accessed on February 2020).

[10] Vukanović, M., Dimitrijević, M.D., Dimitrijević, M.N., Karajićić, L. J., D. Rajčavić, Navala, M., Urošević M., Malešević, M., Trifunović, S., Serdar, R., Altin, B. (1982). Basic Geological Map SFRJ, Podujevo K 34-43 (1:100000) 1984-1975, Geološki Institut, Belgrade, Serbia. (In Serbian).

[11] Bogdanović, P., Urošević, M., Urošević, D., M.D. Dimitrijević, B. Marković, A. Pavić, L. J. Menković, K. Folgić, (1970). Basic Geological Map SFRJ, Titova Mitrovica (Novi Pazar K 34-30) 1:100000, 1972-1977, Geološki Institut, Belgrade, Serbia. (In Serbian).

[12] Topographic Map 1:25000, 1970-1979 (1972), Vojnogeografski Institut. Available online: http://www.vgi.mod.gov.rs/ (accessed on February 2020)

[13] Zvonko, T. (2015) "Tunnels and underground structures - authorized text of the lectures - script GN206", Podgorica, Montenegro. (In Serbian).

[14] Sautya, M. (2020) “Shapes of Tunnels". Available online: https://civilnoteppt.com/shapes-of-tunnels/ (accessed on April, 2020).

[15] Pauri, A. (2019). Ground improvement carried out via an existing railway tunnel for the construction of a new underlying tunnel. Tunnels and Underground Cities: Engineering and Innovation Meet Archaeology, Architecture and Art, $1428-1437$. doi:10.1201/9780429424441-152.

[16] Yamany, M. S., \& Elwakil, E. (2020). Modelling of cast-in-place concrete tunnel liners condition. Structure and Infrastructure Engineering, 16(8), 1147-1160. doi:10.1080/15732479.2019.1687529.

[17] Machelski, C. (2020). The use of the collocation algorithm for estimating the deformations of soil-shell objects made of corrugated sheets. Studia Geotechnica et Mechanica, 42(4), 319-329. doi:10.2478/sgem-2019-0048.

[18] Pan, R., Zhu, G., Liang, Z., Zhang, G., Liu, H., \& Zhou, X. (2020). Experimental study on the fire shape and maximum temperature beneath ceiling centerline in utility tunnel under the effect of curved sidewall. Tunnelling and Underground Space Technology, 99, 103304. doi:10.1016/j.tust.2020.103304.

[19] Luo, Y., Gong, F., Liu, D., Wang, S., \& Si, X. (2019). Experimental simulation analysis of the process and failure characteristics of spalling in D-shaped tunnels under true-triaxial loading conditions. Tunnelling and Underground Space Technology, 90, 4261. doi:10.1016/j.tust.2019.04.020. 